\title{
Giant cell arteritis: is the clinical spectrum of the disease changing?
}

\author{
Miguel Á. González-Gay ${ }^{1,2,3^{*}}$ (D, Miguel Ortego-Jurado ${ }^{4}$, Liliana Ercole ${ }^{5}$ and Norberto Ortego-Centeno ${ }^{6}$
}

\begin{abstract}
Background: Giant cell arteritis is a vasculitis of large and middle-sized arteries that affects patients aged over 50 years. It can show a typical clinical picture consisting of cranial manifestations but sometimes nonspecific symptoms and large-vessel involvement prevail. Prompt diagnosis and treatment is essential to avoid irreversible damage.

Discussion: There has been an increasing knowledge on the occurrence of the disease without the typical cranial symptoms and its close relationship and overlap with polymyalgia rheumatica, and this may contribute to reduce the number of underdiagnosed patients. Although temporal artery biopsy is still the gold-standard and temporal artery ultrasonography is being widely used, newer imaging techniques (FDG-PET/TAC, MRI, CT) can be of valuable help to identify giant cell arteritis, in particular in those cases with a predominance of extracranial large-vessel manifestations.

Conclusions: Giant cell arteritis is a more heterogeneous condition than previously thought. Awareness of all the potential clinical manifestations and judicious use of diagnostic tests may be an aid to avoid delayed detection and consequently ominous complications.
\end{abstract}

Keywords: Giant-cell arteritis, Polymyalgia rheumatica, FDG-PET/CT

\section{Background}

Giant cell arteritis (GCA) is a non-necrotizing granulomatous vasculitis affecting large and middle-sized arteries. Histologic changes, mainly inflammatory infiltrates with the presence of multinucleated giant cells between the media and intima layers and disruption of the internal elastic lamina, ultimately leads to partial or complete obstruction of local arterial blood flow with the corresponding clinical manifestations of ischemia [1-6]. Branches of the aortic arch are most often affected. However, non-specific clinical features related to the general inflammatory state, such as low-grade fever, malaise, fatigue, constitutional symptoms or anemia, may prevail in some cases. In this later group of patients, a lower index of suspicion may yield a significant diagnostic and therapeutic delay with potential serious consequences [7]. In addition, involvement of the aorta is associated with a higher risk for developing aneurysms and dissection over

\footnotetext{
* Correspondence: miguelaggay@hotmail.com

${ }^{1}$ Division of Rheumatology and Epidemiology, Genetics and Atherosclerosis Research Group on Systemic Inflammatory Diseases, Hospital Universitario Marqués de Valdecilla, Instituto de Investigación Marqués de Valdecilla, 39011 Santander, Spain

${ }^{2}$ University of Cantabria, Santander, Spain

Full list of author information is available at the end of the article
}

the course of the disease, especially in the thoracic segment [8-10].

Most common local symptoms include acute headache, scalp pain, jaw, tongue or limb claudication, and visual deficits. Clinical features of polymyalgia rheumatica (PMR) may be present before, simultaneously or after diagnosis of GCA has been established [11, 12]. Other findings may occur in a minor proportion, including peripheral neuropathy, dry cough, sore throat or stroke [13]. It is remarkable that strokes affect more often the vertebrobasilar territory at early stages and the carotid branches during follow-up [14, 15]. In rare cases, complete arterial occlusion can end in infarction of distal territories such as the scalp, tongue or limbs.

Ocular involvement may lead to irreversible visual loss, one of the most feared complications, and, for this reason, early diagnosis and treatment of GCA is of major importance. It usually presents as an anterior optic ischemic neuropathy or less commonly as retinal artery occlusion. In addition, visual impairment can be the result of stroke affecting the vertebra-basilar territory [16]. Previous episodes of amaurosis fugax have been associated with an increased risk for permanent visual loss [16]. Other ocular manifestations such as 
episcleritis, scleritis or extraocular muscle palsies are less commonly reported [17-19].

On physical examination, it is important to look for abnormalities in temporal arteries (i.e. thickening, tenderness, beading or reduced pulsation) [20, 21], but attention must also be focused on the remaining peripheral arterial territories to disclose pulse deficits, bruits or asymmetric arterial pressure measurements in any of the four limbs [22]. Although there is no specific laboratory marker for the disease, acute phase reactants (platelets, erythrocyte sedimentation rate and/or $\mathrm{C}$ reactive protein) are elevated in the majority of patients [23]. Conversely, normal values are not sufficient to rule out the diagnosis when there is a strong clinical suspicion. Anemia can also be present, as well as raised liver enzymes [2, 13, 23].

Temporal artery biopsy, performed with appropriate technique, is considered the gold-standard for diagnosis [1]. Nevertheless, the most recent EULAR guidelines consider that early imaging test, such as temporal artery ultrasound, performed by a trained specialist using appropriate operational procedures and settings, may be an alternative to the temporal artery biopsy [24]. Treatment should not be delayed due to pending biopsy results, and it has been demonstrated that histologic changes are recognizable within two weeks after starting therapy $[25,26]$. Advances in imaging over the last few years have constituted a major step forward in the diagnosis of GCA. Besides the use of duplex ultrasonography of the temporal artery for the diagnosis of GCA in patients presenting with the typical pattern of cranial manifestations, other Imaging techniques, such as magnetic resonance, computed tomography (CT)-angiography, and [18F]-fluorodeoxyglucose (FDG)-positron emission tomography (PET/CT) can help to diagnose patients with predominant extracranial manifestations, many of them presenting with atypical manifestations of the disease [24]. These new imaging techniques allows to identify clinically silent large vessel involvement [27]. Experts in the field consider that in some cases they may also be used to monitor response to treatment.

Glucocorticoids are the cornerstone of treatment [2-6]. Some adjuvant therapies, such as methotrexate, have been used as glucocorticoid-sparing agents, thus minimizing their adverse effects, with conflicting results in terms of safety and clinical benefit [28]. It is also recommended to use low-dose aspirin to reduce the risk of associated cardiovascular events $[20,29,30]$. More recently, open-label studies and clinical trials have shown that the use tocilizumab, a novel humanized monoclonal antibody against IL-6, yields significant efficacy in achievement of sustained, corticosteroid-independent remissions [31, 32].

The aim of this report is to help physicians to early recognize symptoms of GCA, with special emphasis on those patients with atypical or extra-cranial manifestations ("occult" GCA), in order to perform an appropriate diagnosis, since it is crucial to prevent severe complications.

\section{Main text \\ Changing epidemiology}

GCA is the most common type of vasculitis in Europe and North America. It is a disease of the elderly, with a peak of prevalence in the seventh and eighth decades of life [33]. In fact, one of the most constant diagnostic criteria has been an age over 50 years. With the progressive expansion of life expectancy over the last decades and the consequent aging of general population, along with shortened periods from disease onset to final diagnosis, the prevalence of GCA tends to increase gradually despite steady incidence rates described in some studies. GCA is usually more frequent in women, with an average ratio around 2:1, and more common in patients of Scandinavian origin $[3,5,13,33]$. A genetic predisposition has been found, with special relevance of some alleles of the HLA class II region, in particular those with HLA-DRB*04 [34, 35].

The etiology is still unknown, but certain parallelism of peak incidences with some infectious outbreaks and detection of viral molecules in biopsy specimens have tempted some investigators to hypothesize than an infection might at least trigger the inflammatory reaction. However, the exact pathogenic explanation of this finding, if any, remains to be elucidated. Microorganisms that have been implicated include varicella zoster virus, Mycoplasma pneumoniae, Chlamydia pneumoniae, and parvovirus B19 [36-38], but infectious agents have not been definitely proven to play a major causal role nor be the sole immunologic trigger [39].

Incidence of GCA was found to increase in some regions [40], in other studies there was a trend towards lower rates [41, 42], and others described stability [43]. Higher awareness of the disease by attending physicians and underestimation of more atypical extra-cranial forms in the past may have played a role in these variations. Interestingly, probably because physicians are more familiar with the disease, some series have shown a decline of visual manifestations in recent years $[18,40,44]$.

\section{GCA and PMR, two overlapping conditions}

PMR is an inflammatory disorder that usually presents as severe pain and stiffness of shoulders and proximal arms. Involvement of other regions, mainly the neck, pelvic girdle and thighs, can also occur. Raised laboratory inflammatory markers are generally observed. Ultrasonographic findings (characteristic bursitis and tenosynovitis) have been added to the latest ACR and 
EULAR preliminary classification criteria [45]. PMR usually has a good and rapid response to glucocorticoid therapy at lower doses than those required for treating GCA [12].

GCA shares epidemiological, physiopathological and clinical features with PMR, and they often overlap in a synchronic or metachronic manner in the same patient [11]. In fact, for some authors they comprise two variants of a single disease. It is estimated that about $20 \%$ of patients with PMR have associated GCA [46, 47], although this frequency was higher, up to $50 \%$, in temporal-artery-biopsy-proven cases [48]. Moreover, when imaging techniques such as FDG-PET/CT are performed in patients with PMR, they have shown that at least one third of them may have large-vessel involvement that may be clinically silent and without associated typical cranial ischemic manifestations [12]. A recent study has disclosed that large-vessel vasculitis involvement is often observed in patients with persistent PMR who have inflammatory low back pain, predominant pelvic girdle and or diffuse limb pain [49].

Therefore, it is advocated that patients with a newly diagnosis of PMR should be screened for large-vessel inflammation and concomitant GCA using clinical predictors [49] and whenever confirmatory imaging techniques were available. In addition, close observation should be maintained over the entire course of the disease, since typical features of GCA and ischemic events (including visual deficits) have been described during the follow-up of patients with an initial diagnosis of isolated PMR, thus requiring higher corticosteroid doses to avoid irreversible damages [50,51], especially blindness [52]. "Pure" (isolated) PMR patients tend to show lower values of inflammatory parameters and milder degrees of anemia and thrombocytosis compared to those with PMR associated with clinical features of GCA [53]. Also, patients with suspected PMR who do not have a good response to low-dose glucocorticoids or show marked systemic symptoms may actually represent a form of extra-cranial GCA [12].

\section{Cranial vs extra-cranial disease}

In recent years there have been a growing interest and knowledge on cases with involvement of extra-cranial territories, in contrast to the "classic" cranial manifestations. Incidence of extra-cranial disease seems to have been underestimated in the past. This was formerly supported by some post-mortem studies and histological analysis of case series of vascular surgery of the aorta or its main branches [54]. The widespread use of wholebody imaging techniques (i.e. FDG-PET/CT and CT or MRI angiography) and a greater awareness of the disease in patients with atypical manifestations will probably raise this incidence even more in the future.
Most patients with a recent diagnosis of temporal-artery-biopsy-proven GCA have no clinical evidence of vascular ischemic manifestations $[48,55]$. However, imaging techniques often show asymptomatic extra-cranial vascular involvement in these patients and support the claim that GCA involves arteries far beyond the temporal and other cranial arteries [56, 57]. Moreover, the risk of developing aortic aneurysm or dissection has been estimated up to 17 times greater than in patients without GCA, additionally increasing when other cardiovascular risk factors such as hypertension are present $[8,10]$. For these reasons, some authors advocate screening imaging of the aorta at the time of diagnosis and during follow-up, since symptoms usually develop several years later $[10,58]$. The presence of cardiovascular risk factors of atherosclerosis at the time of diagnosis of GCA may influence the development of severe ischemic manifestations of the disease [59]. On the other hand, some authors consider that GCA patients with a pattern of extra-cranial vascular involvement, without the typical cranial ischemic manifestations of the disease, have lower risk of having ophthalmologic complications over the course of the disease, but in turn they are more prone to relapses and large-vessel complications [60, 61].

Isolated extra-cranial GCA represents a diagnostic challenge since signs and symptoms may be nonspecific (fever, fatigue, weight loss) unless local ischemic manifestations appear. A significant proportion of patients with ischemic features attributed to atherosclerosis or embolic origin could represent an extra-cranial form of this vasculitis, particularly when cardiovascular risk factors are scarce or absent. In addition, laboratory inflammatory markers tend to be lower in this group of patients [62]. This difficulty in diagnosis often leads to a greater diagnostic delay compared with patients suffering typical cranial symptoms [7, 63]. Interestingly, patients with predominant large-vessel-vasculitis pattern are younger and have more commonly PMR features and longer duration of symptoms at GCA diagnosis than those with predominant cranial manifestations [60, 61]. Moreover, the frequency of a positive temporal artery biopsy in these is much lower than in those with the classic pattern of GCA [60,63]. Because of that, in these patients the diagnosis must often be relied on large-vessel inflammatory signs on imaging tests, as retrieval of arterial specimens in other territories entails significant morbidity.

\section{Current diagnostic tools and diagnostic challenges}

Although temporal artery biopsy is considered by many clinicians as the gold-standard for the diagnosis of GCA [1], focal or segmental inflammatory changes and technical pitfalls of the procedure make it difficult to confirm this condition in a significant proportion of 
patients. Diagnostic yield of biopsy varies greatly depending on the length of the excised specimen and whether it is performed unilaterally or bilaterally $[64,65]$. The traditional recommendation was to obtain an arterial sample of at least $2-3 \mathrm{~cm}$ of length, although more recent studies consider that $1 \mathrm{~cm}$ could be enough for histologic diagnosis.

Some authors have designed predictive models as an aid to select those patients with higher probability of having GCA, but it should be kept in mind that these calculators do not take into account those cases of GCA with a negative biopsy result [66].

Color duplex ultrasonography has been proposed as a harmless, noninvasive and readily available alternative to temporal artery biopsy for diagnostic purposes [3, 67]. With the demonstration of arterial wall edema (known as the "halo sign") it may reach a specificity above $90 \%$ [3]. However, sensitivity tends to be lower, it is an operator-dependent technique, and specificity may be decreased in patients with atherosclerotic disease [68]. Ultrasonography must therefore be performed by personnel with expertise in the field, in order to avoid false positive and false negative results. Although it could also be an aid to localize the most affected temporal arterial segment for histologic assessment, some studies have not shown superiority of this strategy compared with non-US-guided biopsy [69].

Cranial arterial wall thickening can also be disclosed by means of contrast-enhanced high-resolution MRI, with sensitivities near $90 \%$, but its usefulness decreases when patients have received treatment for more than 5 days and it is a more expensive and less available technique [70-72]. With respect to this, the central bright spot sign (optic nerve head enhancement on MRI) has been proposed as a useful tool to distinguish acute stage GCA from other nonarteritic anterior ischemic optic neuropathies [73].

The use FDG-PET/CT in patients with suspected or confirmed GCA has been progressively increasing in recent years. It allows detection of large-vessel involvement prior or after diagnosis has been made [3, 48, 74] and has special value when there is suspicion of isolated extra-cranial disease [58]. Nevertheless, it is an expensive and not universally available technique and is associated with radiation exposure. Moreover, its sensitivity decreases in patients undergoing glucocorticoid therapy. Some studies comparing FDG-PET/CT and CTangiography have shown similar sensitivities for both modalities regarding disclosure of large-vessel inflammation, although the former seems to have a higher positive predictive value [75-77]. A cutoff value of $>2.2 \mathrm{~mm}$ of aortic wall thickening measured by $\mathrm{CT}$ scan has been suggested for diagnostic purposes [78]. The remarkably improved performance of all these imaging modalities and their increasing availability are reflected in the recently published EULAR recommendations, which stated that temporal artery biopsy could be obviated in patients with a strong clinical suspicion and a positive, reliable imaging test [24].

In addition to imaging advances, measurement of autoantibodies against ferritin has also been reported as an alternative diagnostic laboratory biomarker, but its usefulness has not been fully demonstrated yet, and it seems far from everyday clinical practice $[79,80]$.

GCA is not always a readily suspected condition. Initial diagnosis often relies on primary care physicians and specialists in Geriatrics, so they should be aware of the importance of a prompt detection to avoid serious and irreversible complications due to the delay in treatment. As discussed before, a typical clinical picture is not

Table 1 "Red flags" on history or physical examination that may suggest GCA

Typical cranial disease

New onset headache (mainly temporal)

Scalp pain

Jaw or tongue claudication

Acute visual deficits

Temporal artery abnormalities on physical examination

Anterior ischemic optic neuropathy or central retinal artery occlusion on ophthalmologic examination

Associated constitutional symptoms

Associated polymyalgia rheumatica symptoms

Associated anemia an elevated $\mathrm{C}$ reactive protein/erythrocyte sedimentation rate

Extra-cranial disease

Ischemic signs and symptoms of extremities, especially in the absence of other cardiovascular risk factors or emboligenic cardiopathy:

Limb claudication

Pulse asymmetry

Arterial pressure asymmetry

Peripheral arterial bruits

Distal necrosis or gangrene

Non-specific manifestations without evidence of infectious o neoplastic disease:

Fever

Weight loss

Fatigue/malaise

Unexplained anemia

Polymyalgia rheumatica that relapses or responds poorly to standard glucocorticoid therapy

Polymyalgia rheumatica with associated ischemic manifestations

Detection of aneurysm or dissection of aorta and main branches along with raised inflammatory markers 
always present. On the other hand, healthy patients with advanced age may have raised values of erythrocyte sedimentation rate. A survey directed to general practitioners in the UK disclosed that more than $20 \%$ of them would rule out GCA if headache was not present among the patient's symptoms [81]. Other study showed that mean delay from initial symptoms to final diagnosis of GCA was 9 weeks, but this period was almost doubled when there were isolated extra-cranial manifestations [7]. It must be emphasized that GCA is a disease with very heterogeneous signs and symptoms, mimicking many common conditions, and therefore physicians should be familiar with this clinical variability (see Table 1) to be able to raise their clinical suspicion. In this regard, it is essential to educate and train primary care physicians and specialists in Geriatrics and to promote and facilitate communication pathways with other specialists to allow earlier diagnosis [81].

Table 2 depicts some practical recommendations to improve management, follow-up and prognosis.

\section{Conclusions}

GCA is an inflammatory disease with very heterogeneous and often nonspecific clinical manifestations that

Table 2 Practical recommendations and learning points in the diagnostic approach and management of GCA

- Former term "temporal arteritis" might be misleading or confounding, as virtually any large or medium-sized artery may be affected.

- GCA may present with isolated extra-cranial involvement.

- PMR may be present before, during or after diagnosis of GCA has been established, and vice versa

- Comprehensive clinical assessment should include palpation of the temporal arteries as well as palpation and auscultation of extracranial vascular territories, including axillary and subclavian arteries, in order to look for any one-sided vascular stenosis. Arterial pressures should also be measured in all four limbs.

- Temporal artery biopsy is the gold standard for the diagnosis of GCA with cranial manifestations. However, the temporal artery yield decreases significantly in patients presenting with extra-cranial GCA.

- Temporal artery biopsy is positive in patients with cranial manifestations even several weeks after the onset of glucocorticoids.

- When there is a very suggestive clinical picture and a positive imaging test, presumptive diagnosis of GCA may be established, thus obviating temporal artery biopsy.

- Glucocorticoid therapy should be started immediately in patients with a high clinical suspicion of GCA, even before histologic confirmation or imaging tests are available.

- When ophthalmologic symptoms are present, high doses of glucocorticoids are recommended.

- After diagnosis of GCA has been established, it may be advisable to use CT-angiography or FDG-PET/CT for screening of large-vessel involvement.

- Large-vessel complications (aneurysm and dissection) may develop several years after initial diagnosis of GCA, therefore long-term close follow-up is advised. can lead to serious and irreversible complications, being visual loss, acute arterial ischemia and acute aortic syndromes the most feared of them. This heterogeneity can lead to a low index of suspicion from attending physicians. It is crucial to establish an early diagnosis and treatment to reduce the risk of developing such complications. It is also important to carry out a close follow-up, since large vessel involvement may occur years after initial recognition of the disease. Newer imaging techniques such as FDG-PET/ CT, MRI or CT-angiography can be an aid for diagnosis and also for follow-up of patients.

\section{Abbreviations}

CT: Computed tomography; FDG-PET: Fluorodeoxyglucose positron emission tomography; GCA: Giant-cell arteritis; MRI: Magnetic resonance imaging; PMR: Polymyalgia rheumatica

\section{Acknowledgements}

Authors would like to thank Dr. Jorge Polo and Dr. Pablo Rivas, on behalf of Springer Healthcare Communications, for medical writing assistance. This assistance was funded by Roche Pharma, Spain.

\section{Authors' contributions}

MAGG made substantial contributions to conception and design, analysis and interpretation of data, was involved in drafting the manuscript and revising it critically and gave final approval of the version to be published. NOC made substantial contributions to conception and design, analysis and interpretation of data, was involved in drafting the manuscript and revising it critically and gave final approval of the version to be published. MOJ made substantial contributions to conception and design, analysis and interpretation of data, was involved in drafting the manuscript and revising it critically and gave final approval of the version to be published. LE made substantial contributions to conception and design, analysis and interpretation of data, was involved in drafting the manuscript and revising it critically and gave final approval of the version to be published.

\section{Funding}

This review was funded by Roche Farma S.A. Spain.

Availability of data and materials

Not applicable.

Ethics approval and consent to participate

Not applicable.

Consent for publication

Not applicable.

\section{Competing interests}

LE is an employee of Roche Farma S.A. Spain.

\section{Author details}

'Division of Rheumatology and Epidemiology, Genetics and Atherosclerosis Research Group on Systemic Inflammatory Diseases, Hospital Universitario Marqués de Valdecilla, Instituto de Investigación Marqués de Valdecilla, 39011 Santander, Spain. ${ }^{2}$ University of Cantabria, Santander, Spain. ${ }^{3}$ Cardiovascular Pathophysiology and Genomics Research Unit, School of Physiology, Faculty of Health Sciences, University of the Witwatersrand, Johannesburg, South Africa. ${ }^{4}$ Emergency Health Services Agency-061 (EPES-061), Granada, Spain. ${ }^{5}$ Medical Department, Roche Pharma, Madrid, Spain. ${ }^{6}$ Autoimmune Diseases Unit, Hospital Universitario San Cecilio, Instituto de Investigación Biosanitaria de Granada (IBS. GRANADA), Department of Internal Medicine, Professor of Medicine of the University of Granada, Granada, Spain. 


\section{Received: 20 September 2018 Accepted: 24 July 2019}

\section{Published online: 29 July 2019}

\section{References}

1. Gonzalez-Gay MA. The diagnosis and management of patients with giant cell arteritis. J Rheumatol. 2005;32(7):1186-8.

2. Weyand CM, Goronzy JJ. Clinical practice. Giant-cell arteritis and polymyalgia rheumatica. N Engl J Med. 2014;371(1):50-7.

3. González-Gay MA, Pina T. Giant cell arteritis and polymyalgia rheumatica: an update. Curr Rheumatol Rep. 2015;17(2):6.

4. Buttgereit F, Dejaco C, Matteson EL, Dasgupta B. Polymyalgia rheumatica and giant cell arteritis: a systematic review. JAMA. 2016;315(22):2442-58.

5. Hoffman GS. Giant cell arteritis. Ann Intern Med. 2016;165(9):ITC65-80.

6. Pradeep S, Smith JH. Giant cell arteritis: practical pearls and updates. Curr Pain Headache Rep. 2018 Jan 17;22(1):2.

7. Prior JA, Ranjbar H, Belcher J, Mackie SL, Helliwell T, Liddle J, et al. Diagnostic delay for giant cell arteritis - a systematic review and metaanalysis. BMC Med. 2017;15(1):120.

8. Evans JM, O'Fallon WM, Hunder GG. Increased incidence of aortic aneurysm and dissection in giant cell (temporal) arteritis. A population-based study. Ann Intern Med. 1995;122(7):502-7.

9. Nuenninghoff DM, Hunder GG, Christianson TJ, McClelland RL, Matteson EL. Incidence and predictors of large-artery complication (aortic aneurysm, aortic dissection, and/or large-artery stenosis) in patients with giant cell arteritis: a population-based study over 50 years. Arthritis Rheum. 2003; 48(12):3522-31.

10. Gonzalez-Gay MA, Garcia-Porrua C, Piñeiro A, Pego-Reigosa R, Llorca J, Hunder GG. Aortic aneurysm and dissection in patients with biopsy-proven giant cell arteritis from northwestern Spain: a population-based study. Medicine (Baltimore). 2004;83(6):335-41.

11. Gonzalez-Gay MA. Giant cell arteritis and polymyalgia rheumatica: two different but often overlapping conditions. Semin Arthritis Rheum. 2004; 33(5):289-93.

12. González-Gay MA, Matteson EL, Castañeda S. Polymyalgia rheumatica. Lancet. 2017;390(10103):1700-12.

13. Salvarani C, Cantini F, Boiardi L, Hunder GG. Polymyalgia rheumatica and giant-cell arteritis. N Engl J Med. 2002;347(4):261-71.

14. Pego-Reigosa R, Garcia-Porrua C, Piñeiro A, Dierssen T, Llorca J, GonzalezGay MA. Predictors of cerebrovascular accidents in giant cell arteritis in a defined population. Clin Exp Rheumatol. 2004;22(6 Suppl 36):S13-7.

15. Gonzalez-Gay MA, Vazquez-Rodriguez TR, Gomez-Acebo I, Pego-Reigosa R, Lopez-Diaz MJ, Vazquez-Triñanes MC, et al. Strokes at time of disease diagnosis in a series of 287 patients with biopsy-proven giant cell arteritis. Medicine (Baltimore). 2009;88(4):227-35.

16. González-Gay MA, García-Porrúa C, Llorca J, Hajeer AH, Brañas F, Dababneh $A$, et al. Visual manifestations of giant cell arteritis. Trends and clinical spectrum in 161 patients. Medicine (Baltimore). 2000;79(5):283-92.

17. Tugal-Tutkun I. Systemic vasculitis and the eye. Curr Opin Rheumatol. 2017; 29(1):24-32.

18. Papaliodis GN. Ophthalmologic manifestations of systemic vasculitis. Curr Opin Ophthalmol. 2017:28(6):613-6.

19. Soriano A, Muratore F, Pipitone N, Boiardi L, Cimino L, Salvarani C. Visual loss and other cranial ischaemic complications in giant cell arteritis. Nat Rev Rheumatol. 2017;13(8):476-84.

20. Dasgupta B, Borg FA, Hassan N, Alexander L, Barraclough K, Bourke B, et al BSR and BHPR guidelines for the management of giant cell arteritis. Rheumatology (Oxford). 2010;49(8):1594-7.

21. Dasgupta B, Giant Cell Arteritis Guideline Development Group. Concise guidance: diagnosis and management of giant cell arteritis. Clin Med (Lond). 2010;10(4):381-6.

22. Ratschiller T, Müller H, Pirklbauer M, Silye R, Sulzbacher G, Zierer A. Giant cell arteritis as unusual cause of critical arm ischemia. J Vasc Surg Cases Innov Tech. 2018;4(3):248-251.

23. Gonzalez-Gay MA, Lopez-Diaz MJ, Barros S, Garcia-Porrua C, Sanchez-Andrade A, Paz-Carreira J, et al. Giant cell arteritis: laboratory tests at the time of diagnosis in a series of 240 patients. Medicine (Baltimore). 2005;84(5):277-90.

24. Dejaco C, Ramiro S, Duftner C, Besson FL, Bley TA, Blockmans D, et al. EULAR recommendations for the use of imaging in large vessel vasculitis in clinical practice. Ann Rheum Dis. 2018;77(5):636-43.
25. Achkar AA, Lie JT, Hunder GG, O'Fallon WM, Gabriel SE. How does previous corticosteroid treatment affect the biopsy findings in giant cell (temporal) arteritis? Ann Intern Med. 1994;120(12):987-92.

26. Narváez J, Bernad B, Roig-Vilaseca D, García-Gómez C, Gómez-Vaquero C, Juanola $X$, et al. Influence of previous corticosteroid therapy on temporal artery biopsy yield in giant cell arteritis. Semin Arthritis Rheum. 2007;37(1):13-9.

27. Loricera J, Blanco R, Hernández JL, Carril JM, Martínez-Rodríguez I, Canga A, et al. Non-infectious aortitis: a report of 32 cases from a single tertiary centre in a 4-year period and literature review. Clin Exp Rheumatol. 2015; 33(2 Suppl 89):S-19-31.

28. Yates M, Loke YK, Watts RA, MacGregor AJ. Prednisolone combined with adjunctive immunosuppression is not superior to prednisolone alone in terms of efficacy and safety in giant cell arteritis: meta-analysis. Clin Rheumatol. 2014;33(2):227-36.

29. Nesher G, Berkun Y, Mates M, Baras M, Rubinow A, Sonnenblick M. Lowdose aspirin and prevention of cranial ischemic complications in giant cell arteritis. Arthritis Rheum. 2004;50(4):1332-7.

30. Lee MS, Smith SD, Galor A, Hoffman GS. Antiplatelet and anticoagulant therapy in patients with giant cell arteritis. Arthritis Rheum. 2006;54(10): 3306-9.

31. Loricera J, Blanco R, Hernández JL, Castañeda S, Mera A, Pérez-Pampín E, et al. Tocilizumab in giant cell arteritis: multicenter open-label study of 22 patients. Semin Arthritis Rheum. 2015:44(6):717-23.

32. Stone JH, Tuckwell K, Dimonaco S, Klearman M, Aringer M, Blockmans D, et al. Trial of tocilizumab in Giant-cell arteritis. N Engl J Med. 2017;377(4):31728.

33. Gonzalez-Gay MA, Vazquez-Rodriguez TR, Lopez-Diaz MJ, Miranda-Filloy JA, Gonzalez-Juanatey C, Martin J, Llorca J. Epidemiology of giant cell arteritis and polymyalgia rheumatica. Arthritis Rheum. 2009;61(10):1454-61.

34. Gonzalez-Gay MA, Amoli MM, Garcia-Porrua C, Ollier WE. Genetic markers of disease susceptibility and severity in giant cell arteritis and polymyalgia rheumatica. Semin Arthritis Rheum. 2003;33(1):38-48.

35. Carmona FD, Mackie SL, Martín JE, Taylor JC, Vaglio A, Eyre S, et al. A largescale genetic analysis reveals a strong contribution of the HLA class II region to giant cell arteritis susceptibility. Am J Hum Genet. 2015;96(4):565-80.

36. Elling $P$, Olsson AT, Elling $H$. Synchronous variations of the incidence of temporal arteritis and polymyalgia rheumatica in different regions of Denmark; association with epidemics of mycoplasma pneumoniae infection. J Rheumatol. 1996;23(1):112-9.

37. Gilden D, White T, Khmeleva N, Heintzman A, Choe A, Boyer PJ, et al. Prevalence and distribution of VZV in temporal arteries of patients with giant cell arteritis. Neurology. 2015;84(19):1948-55.

38. Nagel MA, White T, Khmeleva N, Rempel A, Boyer PJ, Bennett $J$, et al. Analysis of varicella-zoster virus in temporal arteries biopsy positive and negative for giant cell arteritis. JAMA Neuro. 2015;72(11):1281-7.

39. Rhee RL, Grayson PC, Merkel PA, Tomasson G. Infections and the risk of incident giant cell arteritis: a population-based, case-control study. Ann Rheum Dis. 2017;76(6):1031-5.

40. Gonzalez-Gay MA, Miranda-Filloy JA, Lopez-Diaz MJ, Perez-Alvarez R, Gonzalez-Juanatey C, Sanchez-Andrade A, et al. Giant cell arteritis in northwestern Spain: a 25-year epidemiologic study. Medicine (Baltimore). 2007;86(2):61-8.

41. Yates M, Graham K, Watts RA, MacGregor AJ. The prevalence of giant cell arteritis and polymyalgia rheumatica in a UK primary care population. BMC Musculoskelet Disord. 2016:17:285.

42. Catanoso M, Macchioni P, Boiardi L, Muratore F, Restuccia G, Cavazza A, et al. Incidence, prevalence, and survival of biopsy-proven giant cell arteritis in northern Italy during a 26-year period. Arthritis Care Res (Hoboken). 2017; 69(3):430-8.

43. Crowson CS, Matteson EL. Contemporary prevalence estimates for giant cell arteritis and polymyalgia rheumatica, 2015. Semin Arthritis Rheum. 2017; 47(2):253-6.

44. Gonzalez-Gay MA, Castañeda S, Llorca J. Giant cell arteritis: visual loss is our major concern. J Rheumatol. 2016;43(8):1458-61.

45. Dasgupta B, Cimmino MA, Maradit-Kremers H, Schmidt WA, Schirmer M, Salvarani C, et al. 2012 provisional classification criteria for polymyalgia rheumatica: a European league against rheumatism/American College of Rheumatology collaborative initiative. Ann Rheum Dis. 2012;71:484-92.

46. Blockmans D, Stroobants S, Maes A, Mortelmans L. Positron emission tomography in giant cell arteritis and polymyalgia rheumatica: evidence for inflammation of the aortic arch. Am J Med. 2000;108(3):246-9. 
47. Ernst D, Baerlecken NT, Schmidt RE, Witte T. Large vessel vasculitis and spondyloarthritis: coincidence or associated diseases? Scand J Rheumatol. 2014;43(3):246-8.

48. Gonzalez-Gay MA, Barros S, Lopez-Diaz MJ, Garcia-Porrua C, Sanchez-Andrade A, Llorca J. Giant cell arteritis: disease patterns of clinical presentation in a series of 240 patients. Medicine (Baltimore). 2005;84(5):269-76.

49. Prieto-Peña D, Martínez-Rodríguez I, Loricera J, Banzo I, Calderón-Goercke M, Calvo-Río V, et al. Predictors of positive (18) F-FDG PET/CT-scan for large vessel vasculitis in patients with persistent polymyalgia rheumatica. Semin Arthritis Rheum. 2018.

50. Narváez J, Estrada P, López-Vives L, Ricse M, Zacarías A, Heredia S, et al. Prevalence of ischemic complications in patients with giant cell arteritis presenting with apparently isolated polymyalgia rheumatica. Semin Arthritis Rheum. 2015;45(3):328-33.

51. Liozon E, de Boysson H, Dalmay F, Gondran G, Bezanahary H, Fauchais AL, et al. Development of Giant cell arteritis after treating polymyalgia or peripheral arthritis: a retrospective case-control study. J Rheumatol. 2018; 45(5):678-85.

52. González-Gay MA, Santiago J, Monte R, Blanco R. Low-dose corticosteroids and blindness in giant cell arteritis. Br J Rheumatol. 1996;35(7):702-3.

53. González-Gay MA, García-Porrúa C, Vázquez-Caruncho M. Polymyalgia rheumatica in biopsy proven giant cell arteritis does not constitute a different subset but differs from isolated polymyalgia rheumatica. J Rheumatol. 1998;25(9):1750-5.

54. Lensen KD, Voskuyl AE, Comans EF, van der Laken CJ, Smulders YM. Extracranial giant cell arteritis: A narrative review. Neth J Med. 2016;74(5):182-92.

55. Gonzalez-Gay MA, Garcia-Porrua C, Amor-Dorado JC, Llorca J. Giant cell arteritis without clinically evident vascular involvement in a defined population. Arthritis Rheum. 2004;51(2):274-7.

56. Blockmans D, de Ceuninck L, Vanderschueren S, Knockaert D, Mortelmans L, Bobbaers H. Repetitive 18F-fluorodeoxyglucose positron emission tomography in giant cell arteritis: a prospective study of 35 patients. Arthritis Rheum. 2006;55(1):131-7.

57. Prieto-González S, Arguis P, García-Martínez A, Espígol-Frigolé G, TaveraBahillo I, Butjosa $\mathrm{M}$, et al. Large vessel involvement in biopsy-proven giant cell arteritis: prospective study in 40 newly diagnosed patients using $\mathrm{CT}$ angiography. Ann Rheum Dis. 2012;71(7):1170-6.

58. de Boysson H, Liozon E, Lambert M, Parienti JJ, Artigues N, Geffray L, et al. 18F-fluorodeoxyglucose positron emission tomography and the risk of subsequent aortic complications in giant-cell arteritis: a multicenter cohort of 130 patients. Medicine (Baltimore). 2016;95(26):e3851.

59. Gonzalez-Gay MA, Piñeiro A, Gomez-Gigirey A, Garcia-Porrua C, PegoReigosa R, Dierssen-Sotos T, Llorca J. Influence of traditional risk factors of atherosclerosis in the development of severe ischemic complications in giant cell arteritis. Medicine (Baltimore). 2004;83(6):342-7.

60. Muratore F, Kermani TA, Crowson CS, Green AB, Salvarani C, Matteson EL, et al. Large-vessel giant cell arteritis: a cohort study. Rheumatology (Oxford). 2015;54(3):463-70

61. Muratore F, Pazzola G, Pipitone N, Boiardi L, Salvarani C. Large-vessel involvement in giant cell arteritis and polymyalgia rheumatica. Clin Exp Rheumatol. 2014;32(3 Suppl 82):S106-11.

62. Lopez-Diaz MJ, Llorca J, Gonzalez-Juanatey C, Peña-Sagredo JL, Martin J, Gonzalez-Gay MA. The erythrocyte sedimentation rate is associated with the development of visual complications in biopsy-proven giant cell arteritis. Semin Arthritis Rheum. 2008:38(2):116-23.

63. Brack A, Martinez-Taboada V, Stanson A, Goronzy JJ, Weyand CM. Disease pattern in cranial and large-vessel giant cell arteritis. Arthritis Rheum. 1999; 42(2):311-7.

64. Breuer GS, Nesher G, Nesher R. Rate of discordant findings in bilateral temporal artery biopsy to diagnose giant cell arteritis. J Rheumatol. 2009; 36(4):794-6.

65. Breuer GS, Nesher R, Nesher G. Effect of biopsy length on the rate of positive temporal artery biopsies. Clin Exp Rheumatol. 2009;27(1 Suppl 52): S10-3.

66. Ing EB, Lahaie Luna G, Toren A, Ing R, Chen JJ, Arora N, et al. Multivariable prediction model for suspected giant cell arteritis: development and validation. Clin Ophthalmol. 2017;11:2031-42.

67. Roncato C, Allix-Béguec C, Brottier-Mancini E, Gombert B, Denis G Diagnostic performance of colour duplex ultrasonography along with temporal artery biopsy in suspicion of giant cell arteritis. Clin Exp Rheumatol. 2017;35(Suppl 103(1)):119-22.
68. De Miguel E, Beltran LM, Monjo I, Deodati F, Schmidt WA, Garcia-Puig J. Atherosclerosis as a potential pitfall in the diagnosis of giant cell arteritis. Rheumatology (Oxford). 2018;57(2):318-21.

69. Germanò G, Muratore F, Cimino L, Lo Gullo A, Possemato N, Macchioni $P$, et al. Is colour duplex sonography-guided temporal artery biopsy useful in the diagnosis of giant cell arteritis? A randomized study. Rheumatology (Oxford). 2015;54(3):400-4.

70. Bley TA, Reinhard M, Hauenstein C, Markl M, Warnatz K, Hetzel A, et al. Comparison of duplex sonography and high-resolution magnetic resonance imaging in the diagnosis of giant cell (temporal) arteritis. Arthritis Rheum. 2008:58(8):2574-8

71. Ghinoi A, Zuccoli G, Nicolini A, Pipitone N, Macchioni L, Bajocchi GL, et al. 1T magnetic resonance imaging in the diagnosis of giant cell arteritis: comparison with ultrasonography and physical examination of temporal arteries. Clin Exp Rheumatol. 2008:26(3 Suppl 49):S76-80.

72. Klink T, Geiger J, Both M, Ness T, Heinzelmann S, Reinhard M, et al. Giant cell arteritis: diagnostic accuracy of MR imaging of superficial cranial arteries in initial diagnosis-results from a multicenter trial. Radiology. 2014;273(3): 844-52.

73. Remond P, Attyé A, Lecler A, Lamalle L, Boudiaf N, Aptel F, et al. The central bright spot sign: a potential new MR imaging sign for the early diagnosis of anterior ischemic optic neuropathy due to Giant cell arteritis. AJNR Am J Neuroradiol. 2017;38(7):1411-5

74. Puppo C, Massollo M, Paparo F, Camellino D, Piccardo A, Shoushtari Zadeh Naseri M, et al. Giant cell arteritis: a systematic review of the qualitative and semiquantitative methods to assess vasculitis with $18 \mathrm{~F}$-fluorodeoxyglucose positron emission tomography. Biomed Res Int. 2014;2014:574248.

75. Lariviere D, Benali K, Coustet B, Pasi N, Hyafil F, Klein I, et al. Positron emission tomography and computed tomography angiography for the diagnosis of giant cell arteritis: a real-life prospective study. Medicine (Baltimore). 2016;95(30):e4146.

76. Hommada M, Mekinian A, Brillet PY, Abad S, Larroche C, Dhôte R, et al. Aortitis in giant cell arteritis: diagnosis with FDG PET/CT and agreement with CT angiography. Autoimmun Rev. 2017;16(11):1131-7.

77. de Boysson H, Dumont A, Liozon E, Lambert M, Boutemy J, Maigné $G$, et al. Giant-cell arteritis: concordance study between aortic CT angiography and FDG-PET/CT in detection of large-vessel involvement. Eur J Nucl Med Mol Imaging. 2017:44(13):2274-9.

78. Berthod PE, Aho-Glélé S, Ornetti P, Chevallier O, Devilliers H, Ricolfi F, et al. CT analysis of the aorta in giant-cell arteritis: a case-control study. Eur Radiol. 2018. https://doi.org/10.1007/s00330-018-5311-8.

79. Baerlecken NT, Linnemann A, Gross WL, Moosig F, Vazquez-Rodriguez TR, Gonzalez-Gay MA, et al. Association of ferritin autoantibodies with giant cell arteritis/polymyalgia rheumatica. Ann Rheum Dis. 2012;71(6):943-7.

80. Régent A, Ly KH, Blet A, Agard C, Puéchal X, Tamas N, et al. Contribution of antiferritin antibodies to diagnosis of giant cell arteritis. Ann Rheum Dis. 2013;72(7):1269-70.

81. Helliwell T, Muller S, Hider SL, Prior JA, Richardson JC, Mallen CD. Challenges of diagnosis and management of giant cell arteritis in general practice: a multimethods study. BMJ Open. 2018;8(2):e019320.

\section{Publisher's Note}

Springer Nature remains neutral with regard to jurisdictional claims in published maps and institutional affiliations.

Ready to submit your research? Choose BMC and benefit from

- fast, convenient online submission

- thorough peer review by experienced researchers in your field

- rapid publication on acceptance

- support for research data, including large and complex data types

- gold Open Access which fosters wider collaboration and increased citations

- maximum visibility for your research: over $100 \mathrm{M}$ website views per year

At $\mathrm{BMC}$, research is always in progress.

Learn more biomedcentral.com/submissions 